\title{
In-situ measurement of formwork pressures generated by Self-Compacting Concrete
}

\author{
M. M. Giammatteo, A. Gregori \& G. Totani \\ Department of Civil Engineering, L'Aquila University, Italy
}

\begin{abstract}
Self-Compacting Concretes (SCC) are a special category of concretes and directions for designing formwork relative to ordinary concretes do not apply to them. In this paper an experimental study on formwork pressure exerted by SCC is reported. The behaviour of the SCC was investigated in instrumented formworks provided for two different types of pressure sensors: common diaphragm pressure transducers and dilatometer cells. In situ measurements of formwork pressure were carried out on walls and concrete columns $6 \mathrm{~m}$ and $9 \mathrm{~m}$ high, $0.30 \mathrm{~m}$ thick and 2.50 or $0.50 \mathrm{~m}$ wide respectively. Successfully, both types of sensor were in agreement describing the continuous time variation of the pressures.
\end{abstract}

Keywords: in-situ measurements, self-compacting concrete, formwork pressures, dilatometer cells.

\section{Introduction}

The horizontal pressure exerted by ordinary plastic concretes is generally calculated as a function of many parameters: final height and casting rate, vibration method, temperature of the environment and of the concrete, nominal dimension and shape of the aggregate, consistency of fresh concrete, setting time, typology of the additives used, formwork's shape. Currently, design purposes for ordinary concrete are various, but the resulting pressure diagrams along the casting height are relatively unvarying (CIRIA [1], ACI [2]).

Unfortunately, recommendations for designing formworks relative to ordinary concretes do not apply to Self-Compacting Concrete (SCC) which represents a relatively new technology developed in Japan since the 1980s (Ozawa et al. [3]). Driven by their own weight, SCCs quickly flow in the formwork and reach an optimum compaction degree without the need for vibration, also in case of 
heavily reinforced structures and/or of a narrow cross section. Saving in manpower is provided and noise pollution is reduced, improving working condition. Apart from the large use in the precast industry, a certain number of technical issues have slowed down its use in cast-in-place applications, in particular due to the lack of knowledge on the lateral pressure that such concrete can exert on formwork systems. In fact, directions for designing formworks relative to ordinary concretes do not apply to SCC, for which the design recommendation to design formwork for full hydrostatic pressure (fluid density of $2400 \mathrm{~kg} / \mathrm{m}^{3}$ ) drastically increases the cost of constructions made of SCC [4].

There are indications, however, confirming the possibility of saving considerable amounts of money when constructing formwork for SCC, because data of pressures measured both in the laboratory (Assaad and Khayat $[5,6]$ ) and in the field (Skarendahl [7], Brameshuber and Uebachs [8], Billberg [9]) often resulted to be lower than hydrostatic. When measured SCC formwork pressure were found to be in agreement with the hydrostatic hypothesis, this behaviour from the concrete was mainly attributed to the effect of relatively high casting rates that, however, not always were higher than in other case with SCC behaving differently.

The reason for so wide a range of literature results is still not clear, therefore extensive campaigns of experimental measurements are required for the validation of new predicting models.

Various techniques have already been adopted, so far, to enquire the concrete behaviour into formwork. Pressure gauges and other alternative devices are often used for investigation curried out in form of experimental size tests and on reduced scale column of concrete cast and monitored into a laboratory. These approaches usually require delicate equipments conceptually more rigorous than other techniques that are more robust, maybe less sensitive but more appropriate for the field. In this second situation, monitoring the stress in the formwork anchors can already provide an indirect measure of the pressure exerted by the concrete (Brameshuber and Uebachs [8]). Although diaphragm pressure transducers have also been used in both the cases of laboratory and field measurements, the use of such kinds of devices has been criticized by Amziane et al. [10], Amziane [11] and Andriamantsilavo and Amziane [12]. They observed that, under the pressure of the fluid (liquid or gas), the membrane of a pressure transducer deforms and produces a variation in both the sensor wire resistance and the output voltage. This, however, makes unsure whether the measurement method suits hardening materials, like concrete, in the setting process. In fact, when the material is setting, the deformation of the transducers diaphragm due to the flow of freshly mixed materials, indeed, is not reversible, although no pressure is applied anymore. Consequently, a displacement controlled procedure can represent the most reliable technique for monitoring the concrete formwork pressures that, eventually, are influenced by the material setting. These authors, therefore, proposed an alternative method based on the balance of zero measurement procedure. Their apparatus, however, results to be as accurate as delicate, making the equipment not suitable for in situ measurement of formwork pressure. 
On the other hand, the same working principle is adopted by dilatometer cells that are currently used, in the geotechnical field, to conduct measures of lateral pressures in the ground (Flat Dilatometer Tests, DMT) (Marchetti [13], Marchetti et al. [14]). The apparatus, as described ahead, is so robust that is usually pushed for many meters deep into ground, being also insensitive to difficulties related to electric power supply (no needed), unstable signals, humidity, dusty etc. This makes the use of dilatometer cells an interesting option for appropriate descriptions of how the lateral pressure on formwork increases during the concreting and decreases with the material setting.

In this paper, data of formwork pressure recorded by using this special technique were compared with those recorded by diaphragm pressure transducers, showing that dilatometer cells represent a reliable and easier alternative to more expensive way to measure formwork pressure.

\section{Experimental investigation}

The behaviour of various commercial SCC mixtures in the formworks was investigated performing in situ measurements of formwork pressure. The cast of real concrete elements took place in formworks designed for casting heights of 6 and $9 \mathrm{~m}$ respectively. Effect on pressure due to different structural shapes was investigate comparing the case of walls and column measuring $2.50 \mathrm{~m}$ and $0.50 \mathrm{~m}$ in wideness and $0.30 \mathrm{~m}$ in thickness. Formworks were instrumented disposing several diaphragm pressure transducers along their height: closer each other at the bottom part of the structure and gradually more spaced going up along the middle span of the main vertical facade. A picture of the wall formwork system is given in Fig. 1 together with the precise position of the sensors.

In addition to pressure transducers, also alternative devices (named dilatometer cells) were applied, for the first time, for measuring formwork pressure in the construction field. Their description is given in the next section. Four of these cells were attached to the instrumented wall formwork system, all aligned at the horizontal level of $1.10 \mathrm{~m}$ from the bottom of the cast. This provided redundancy in the acquisitions, and the mean of four measurements was assumed as value of the concrete formwork pressure at that level. This value was than compared with the readings from the pressure transducers mounted immediately above and below the four cells alignment.

Pore water pressure in concrete mass was also detected, and a specific measuring devise was properly designed for this task. Two of this pore water pressure measuring devices were mounted, one for each side of the formwork, at the level of $1.10 \mathrm{~m}$ from the structure bottom. The mean of the two readings was assumed as value of pore water pressure at that depth.

Lateral pressures exerted by the tested SCCs were monitored during the filling of the formwork and for several hours after the end of the casting.

Effect of various casting rate on concrete formwork pressure was investigate by repeating tests at different speeds. The adopted filling rates ranged from $3 \mathrm{~m} / \mathrm{h}$ to $12 \mathrm{~m} / \mathrm{h}$. Due to the limited amount of concrete required for a test, and according to the mixing and pumping truck limitations, low values of the casting rate were respected dividing the cast in layers and suspending the discharge of 
the concrete between a layer and the next. Height of these layers was fixed in $1 \mathrm{~m}$. Measurements of formwork pressure were carried out right after the discharge of any layer and repeated right before the cast of the next.
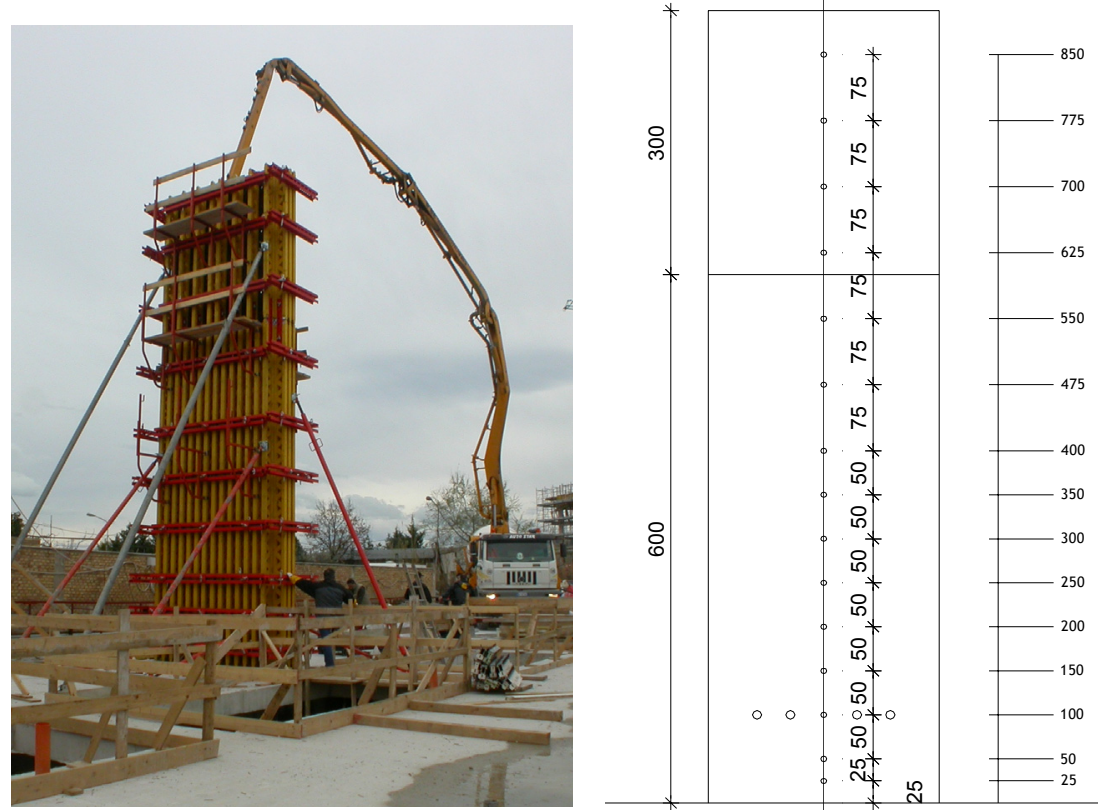

Figure 1: Wall casting and sensors positions.

\subsection{The dilatometer cell}

In the geotechnical field, dilatometer cells are known for being used in Flat Dilatometer Tests (DMT). They provide measures of pressure according to a displacement control procedure (Marchetti [13], Marchetti et al. [14] and Totani et al. [15]). Bigger, more robust and easier to be used than diaphragm pressure transducers, this type of sensors (Fig. 2a) consist in a $60 \mathrm{~mm}$ diameter circular steel membrane $(0.2 \mathrm{~mm}$ in thickness $)$ that, as result of an applied internal gas pressure, expands into the material which pressure has to be measured. The cells were attached to the formwork with its membrane being flush with the inside formwork surface.

The in-situ test layout is given in Fig. 2b: the cell is connected to a control unit by a pneumatic-electrical tube transmitting the gas pressure and the electrical continuity. A gas tank, connected to the control unit by a pneumatic cable, supplies the gas pressure required to expand the membrane. The working principle of the cell is illustrated in Fig. 3a. During the pressure measurement, the dilatometer cell works as an electric switch (on/off). First the external lateral pressure keeps the membrane touching the cell body and the control unit emits a sound (circuit close). Now the operator starts increasing the internal pressure and, for some time, the membrane does not move and remains in contact with its 
metal support (signal on). When the internal pressure counterbalance the external concrete pressure, the membrane starts moving and loses contact with its support (signal off). This causes the interruption of the signal and sound stops, so prompting the operator to read on the manometer (Fig. 3b) the "liftoff' lateral pressure.

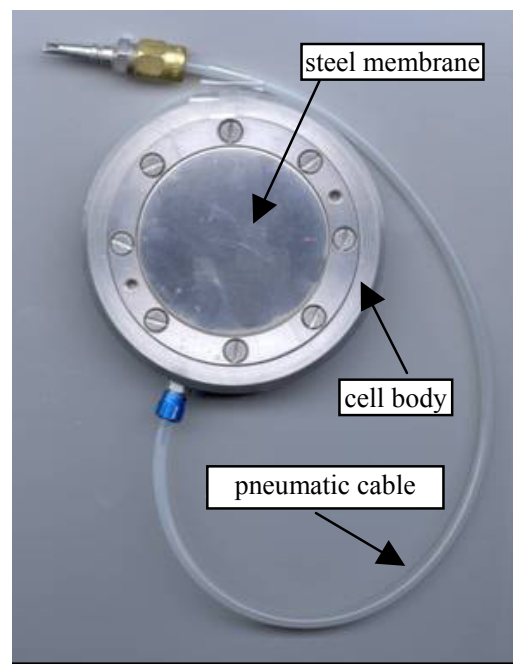

(a)

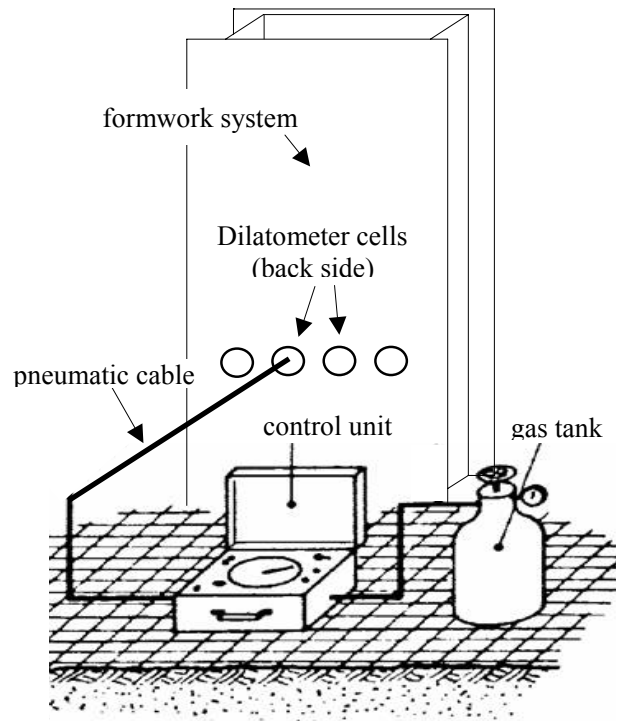

(b)

Figure 2: (a) Detail of a dilatometer pressure cell; (b) general layout of the in situ dilatometer test method.

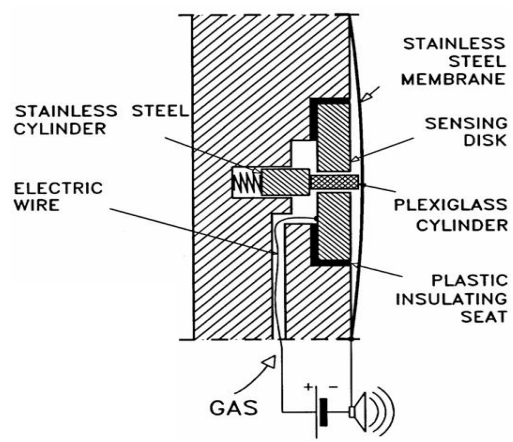

(a)

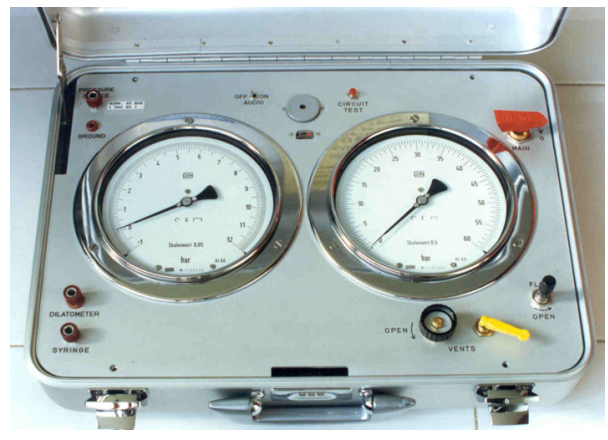

(b)

Figure 3: (a) Dilatometer cell working principle; (b) control unit: manometers for pressure reading. 
Due to the balance of zero pressure measurement method (null method), the dilatometer cell readings are highly accurate $(1 / 20 \mathrm{bar}=5 \mathrm{kPa})$. Moreover, the entire equipment can measure values of pressure as high as $10 \mathrm{MPa}$ and over.

\subsection{Self-Compacting Concrete mixtures}

Two SCC mixtures were tested. The basic combinations of ingredients, called Mixture A and B respectively, are indicated in table 1.

Table 1: $\quad$ SCC mixtures dosages.

\begin{tabular}{|cc|c|c|}
\hline Materials & & Mixture A & Mixture B \\
\hline Sand $(0-6 \mathrm{~mm})$ & $\mathrm{kg}$ & 974 & 916 \\
\hline Coarse aggregate $(7-15 \mathrm{~mm})$ & $\mathrm{kg}$ & 650 & 721 \\
\hline Portland Cement $(32,5)$ & $\mathrm{kg}$ & 355 & 400 \\
\hline Filler & $\mathrm{kg}$ & 170 & 146 \\
\hline Superplasticizer & $\mathrm{lt}$ & 8.88 & 10.00 \\
\hline Viscosity modifying agent & $\mathrm{lt}$ & 1.00 & 1.50 \\
\hline Water/Cement & & 0.52 & 0.41 \\
\hline Water/Binder & & 0.35 & 0.30 \\
\hline
\end{tabular}

In order to maintain the desired condition of fluidity and prevent slump loss, use of different chemical admixtures where required (superplasticizers and set retarding). Several tests were first performed on Mixture A, and later on mixture $\mathrm{B}$, this last designed to have similar fresh property than in case A with a reduced water/binder ratio from 0.35 to 0.30 . Compared to mixture $\mathrm{A}$, thixotropic behaviour of mixture $\mathrm{B}$ should be so increased and, consequently, lateral pressure exerted on formwork potentially reduced. An example of the SCC fluid behaviour is given in Fig. 4, were the concrete slump flow is being measured after the Abrams cone test.

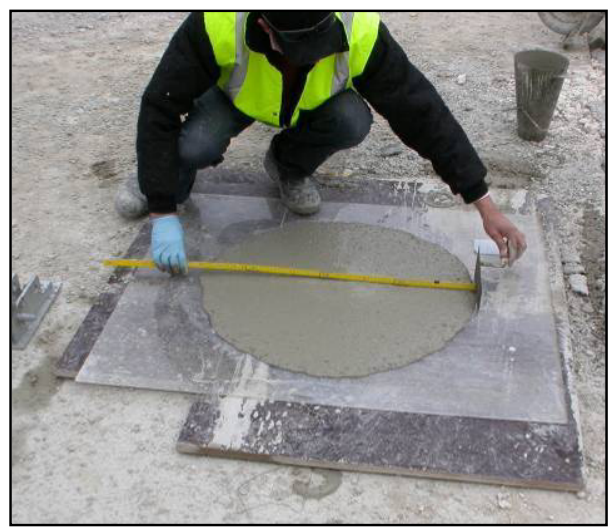

Figure 4: Abrams cone test: SCC slump flow. 


\section{Results and discussion}

Tests were performed on different days. Collected data of formwork pressure are exposed by graphs indicating the evolution of the lateral pressure during the filling of the formwork and after the casting end. Fig. 5 shows data of formwork pressures collected during the cast of a $6 \mathrm{~m}$ high wall performed at the casting rate of $12 \mathrm{~m} / \mathrm{h}$. Mixture A was used with a slump flow diameter of $620 \mathrm{~mm}$. SCC was found to behave in a perfect hydraulic way, maybe due to the combined effect of the set-retarding agent incorporated in the mix and the relatively high casting rate adopted.

Broken lines in Fig. 5 highlight that also when DMT measures (star dots in the graph) did not overlap the pressure profile indicated by the transducers, data kept maintaining the alignment with the pressure transducers readings made immediately over and below the dilatometer cells level. This indicates that DMT technique can result in a reduced data scattering compared with use of common diaphragm pressure transducers.

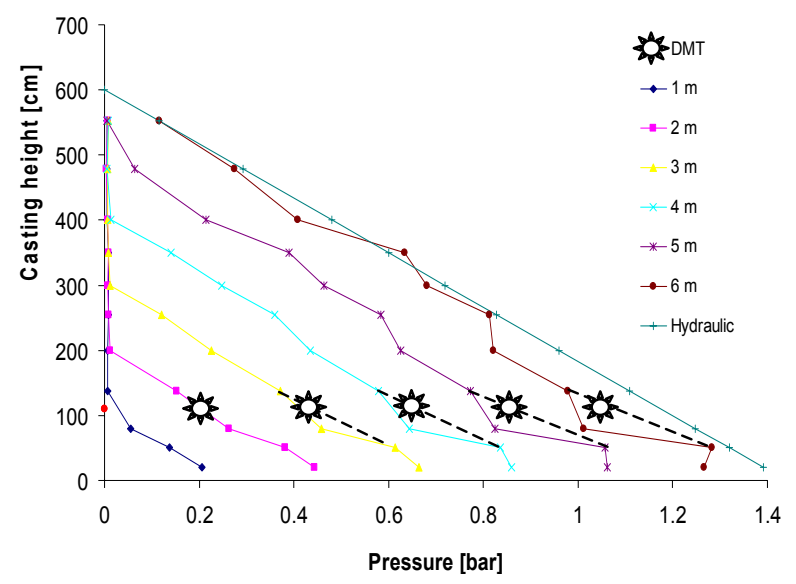

Figure 5: Formwork pressure profiles during the cast of a $6 \mathrm{~m}$ high wall adopting Mixture A. Casting rate $12 \mathrm{~m} / \mathrm{h}$.

Formwork pressures were recorded for several minutes after the casting end as well. Pressure profile was found to reduce quite fast with time (Fig. 6).

This suggests that adoption of lower casting rate values can help reducing the initial formwork pressure. In both Figs. 5 and 6, a perfect agreement can be seen between readings of formwork pressure collected by the diaphragm pressure transducers and the dilatometer cells respectively. DMT technique confirmed good performances and consistency also in different cases of in situ measurements of SCC formwork pressures. Also data collected on column shape structures instead of wall structures showed that readings of pressure curried out by dilatometer cells are fast and reliable and always in good agreement with those performed by the diaphragm pressure transducers. 
A last experiment was carried out monitoring the cast of a $9 \mathrm{~m}$ high wall built at the casting rate of $4 \mathrm{~m} / \mathrm{h}$. Mixture B was used adopting a slump flow diameter of $680 \mathrm{~mm}$. According to references Ferron et al. [16] and Gregori et al. [17], reduction in water and increase in superplasticizer dosages enhanced the thixotropyc behaviour of concrete. As expected, this provided some benefit on formwork pressures that, in fact, were found to deviate from the hydrostatic hypothesis already several meters before the casting end. Figure 7 shows that Mixture B maintained a perfect fluid behavior until the concrete level into formwork did not exceed $5 \mathrm{~m}$ in height.

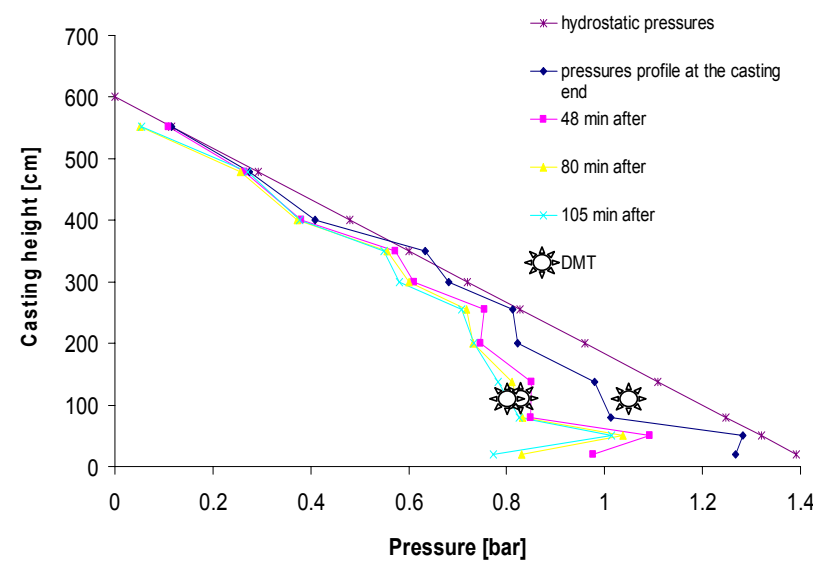

Figure 6: Evolution of the formwork pressure profile with time after the end of the cast.

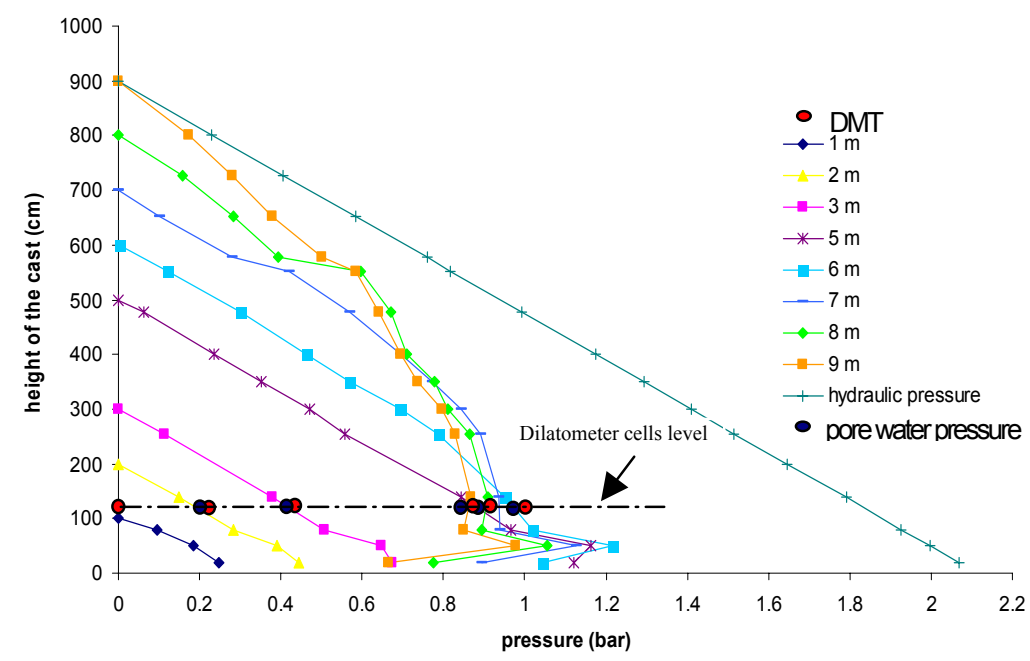

Figure 7: Formwork pressures growth during the cast of a $9 \mathrm{~m}$ high wall using Mixture B. Adopted casting rate: $4 \mathrm{~m} / \mathrm{h}$. 
Keep casting above this level, formwork pressures stopped to grow at the bottom of the structure where, at the end of the casting, only $50 \%$ of the hydraulic pressure was measured. Data in the graph highlight that formwork pressure measured by diaphragm pressure transducers and dilatometer cells were in good agreement confirming this particular concrete behaviour.

Pore water pressures in the concrete mass were also measured. At any stage of the concrete casting, response of the measuring apparatus to the variations of pore water pressure resulted instantaneous. The mean of two readings, taken at $1 \mathrm{~m}$ from the bottom on both sides of the formwork, is indicated in Fig. 7 with blue dot signs. It can be noted that, according with laboratory results concerning simple cement pastes (Andriamanantsilavo and Amziane [12]), also in situ measurements of pore water pressures in concrete were found to be identical to the total lateral stress on formworks.

\section{Conclusions}

In this paper, results from an experimental campaign of study carried out in the construction field were reported. Lateral pressures exerted by different SCC mixtures were monitored in situ by use of instrumented formworks. Two different methods for measuring concrete formwork pressure were compared. Pore water pressure measurements in concrete mass were also curried out: specific devices designed and built on purpose were applied.

Although intense work still have to be done in order to provide complete models for predicting SCC formwork pressures, the following main conclusions can be drawn:

Lateral pressures exerted by fresh concrete into formwork can be monitored according to several approaches. Use of diaphragm pressure transducers can provide accurate description of the total lateral pressures profile along the formwork height. Formwork pressures decay due to the concrete setting is also detectable by the transducers. Electro-working devices, however, are usually delicate and expensive, requiring special cares to be managed and used in situ. Dusty, humidity and mechanical shocks are all undesired factors representing hindrances to a their direct application in the construction field.

In alternative to diaphragm pressure transducers, DMT system represents a robust, cheap and sensitive technique able to provide high reliable in situ measures of concrete formwork pressures. In addition, also building cost of pore water measuring devices is relatively low. They have been used already for a long time in the geotechnical field, and here it has been proved that they can provide correct measures of the concrete formwork pressure in situ.

\section{References}

[1] CIRIA (Civil Industries Research and Information Association); The pressure of concrete on formwork, Research Report No. 1, London, 1965.

[2] ACI Committee 347-01. Guide to Formwork for Concrete, American Concrete Institute, Farmington Hills, MI, 32 pp., 2001. 
[3] Ozawa, K., Naekawa, K., Kunishima, M. \& Okamura, H., Development of high-performance concrete based on the durability design of concrete structures, Proc. $2^{\text {nd }}$ East Asia and Pacific Conference on Structural Engineering and Construction (EASEC-2), pp. 445-450, 1989.

[4] ACI Committee 347R-03. Guide to Formwork for Concrete, American Concrete Institute, Farmington Hills, MI, 32 pp., 2004.

[5] Assaad, J. \& Khayat, K.H., Effect of Coarse Aggregate Characteristics on Lateral pressure Exerted by Self-Consolidating Concrete, ACI Material Journal, V. 102, No. 3, pp. 145-153, 2005.

[6] Assaad, J. \& Khayat, K.H., Formwork Pressure of Self-Consolidating Concrete Made with Various Binder Types and Contents, ACI Material Journal, V. 102, No. 4, pp. 215-223, 2005.

[7] Skarendahl, A., Self-Compacting Concrete for Improved Productivity, Working Environment, and Performance, IREX-Meeting, Paris, 12 pp, 1999.

[8] Brameshuber, W. \& Uebachs, S., Investigations on the Formwork Pressure Using Self-Compacting Concrete, $3^{\text {rd }}$ International Symposium on SelfCompacting Concrete, Reykjavik, Iceland, pp. 281-287, 2003.

[9] Billberg, P., Form Pressure Generated by Self-Compacting Concrete, $3^{\text {rd }}$ International Symposium on Self-Compacting Concrete, $3^{\text {rd }}$ International Symposium on Self-Compacting Concrete, Reykjavik, Iceland, pp. 271-280, 2003.

[10] Amziane, S., Andriamanantsilavo, N.R. \& Bandeau, P., An Experimental Study on the Pressure of Cement Based Materials Against Formwork, $15^{\text {th }}$ ASCE Engineering Mechanics Conference, Columbia University, New York, NY, 8 pp., 2002.

[11] Amziane, S., Setting Time Determination of Cementitious Materials Based on Measurements of the Hydraulic Pressure Variations, Cement and Concrete Research, 2005.

[12] Andriamanantsilavo, N.R. \& Amziane, S., Maturation of fresh Cement Paste Within 1 to $10 \mathrm{~m}$ Large Formwork, Cement and Concrete Research 34, pp. 2141-2152, 2004.

[13] Marchetti, S., In Situ Tests by Flat Dilatometer, ASCE Journal GED, Vol. 106, No. GT3, pp. 299-321, 1980.

[14] Marchetti, S., Monaco, P., Totani, G. \& Calabrese, M., The flat dilatometer test (DMT) in soil investigations, Report by the ISSMGE Committee TC16, Proc. of the $2^{\text {nd }}$ Int. Conf. on the Flat Dilatometer, Washington, D.C., pp. 848, 2006.

[15] Totani, G., Calabrese, M. \& Monaco, P., Shaft resistance of piles driven in clay: field study of an instrumented full scale pile. Workshop in Pile foundations experimental investigations, analysis and design, Napoli, Italy, pp. 199-253, 1994.

[16] Ferron, R., Gregori, A., Sun, Z. \& Shah, S. P., Rheological method to evacuate structural build-up in SCC cement pastes, ACI Materials Journal, publication in press.

[17] Gregori, A., Ferron, R., Sun, Z. \& Shah, S. P., Experimental simulation of SCC formwork pressure, ACI Materials Journal, publication in progress. 